\title{
縦隔鏡生検による肺癌リンパ節転移診断における 細胞診の有用性
}

Imprint cytology for detecting metastasis of lung cancer in mediastinal lymph nodes

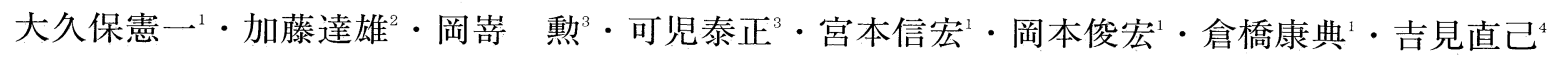

要旨：肺癌の縦隔リンパ節転移診断における細胞診の有用性について検討した. 縦隔鏡生検 50 例 140 stations のリ ンパ節への転移の有無を捺印細胞診および組織診にて行った. 両方の結果を得た後，同一病理医にて最終診 断し, 細胞診・組織診の診断能を判定した. 細胞診では 14 例 22 stations で転移陽性で, 組織診では 12 例 18 stations で転移陽性であった. 組織診陽性例はすべて細胞診陽性であり, 細胞診陽性例がすべて最終的に転移 陽性と判断された. 細胞診の sensitivity, accuracy はともに 100\%で, 組織診のそれは $81.8 \%, 97.1 \%$ であっ た. 縦隔鏡リンパ節生検における細胞診の sensitivity, accuracy は高く，その診断能は組織診と同等かそれ以 上と考えられた。

〔肺癌 40 (2) : 107 110, 2000, JJLC $40: 107 \sim 110,2000$ ]

Key words : Cytodiagnosis, Lung cancer, Lymph node, Mediastinoscopy, Biopsy

\section{はじめに}

画像診断による縦隔リンパ節転移の質的評価は不正確 である現在, 肺癌の病期決定において縦隔鏡検査 ${ }^{11}$ の必要 性が指摘されている．細胞診は組織固定のできないよう な小さな検体の顕微鏡診断に有用であり, またその簡便 性といった特長を有している2 . 肺癌の縦隔鏡生検リン パ節転移診断における細胞診の有用性について検討し た。

\section{対象および方法}

1997 年 4 月より 99 年 5 月に国立療養所岐阜病院で肺 癌病期の決定のために行われた縦隔鏡リンパ節生検症例 は 53 例 154 stations であり，これは同期間肺癌切除手術 131 例中の $40.4 \%$ であった.このうち生検リンパ節の細 胞診と組織診が両方行われたのは 50 例 140 stations で, これを検討の対象とした.内訳は男性 42 例, 女性 8 例 で, 平均年齢 $65.1 \pm 8.3$ 歳 (34 78 歳), 組織型は扁平上 皮癌 22 例, 腺癌 24 例, 大細胞癌 3 例, 小細胞癌 1 例で あった，縦隔鏡にて生検を行ったリンパ節は，\#1(上縦 隔上部） 3 例，\#2（気管傍）13 例，\#3（気管前） 46 例，＃（気管気管支）31 例，\#7（気管分岐部）37 例, 対側２２２例, 対側＃９例であった. 生検により採取さ れたリンパ節は，即座に 2 分割した割面をスライドグラ スに捺印し, 95\%エタノール固定の後, パパニコロウ染
1. 国立療養所岐阜病院呼吸器外科
2. 同 呼吸器内科
3. 同検查科
4. 岐阜大学第一病理

色にて細胞診の判定を行った. 複数小片となる場合は, 個々の小片の各割面を 1station につきスライドグラス 1 枚に捺印した.残りの組織をホルマリン固定し,パラフィ ン包埋後へマトキシリンエオジン染色にて, 組織学的に 転移の有無を判定した. パラフィン包埋はstation 単位と し, 包埋後の最大径となる 1 スライス面での検索とした. この両方の結果を得てから, 同一病理医により, リンパ 節転移の有無を病理組織学的に最終判定した. 最終判定 の結果に基づいて, 細胞診・組織診の感受性・特異性・ 精度を測定した.

\section{結 果}

50 例 140 stations のうち, 細胞診でリンパ節転移陽性 とされたものは 14 例 22 stations で, 組織診で転移陽性 とされたものは 12 例 18 stations であった. 組織診陽性 のリンパ節はすべて細胞診陽性であり，4例 4 stations で細胞診のみ陽性と判定された，細胞診陽性リンパ節が すべて最終的に転移陽性と判断された. 細胞診と組織診 で乘離が見られた症例を Table 1 に示し, 細胞診・組織 診とも陽性, 細胞診のみ陽性の代表的症例を Fig. 1 3 に示した。

細胞診のsensitivityは100\%で, 組織診のそれは81.8\% であった.specificity は細胞診・組織診とも100\%で, accuracy は細胞診で100\%, 組織診で $97.1 \%$ であった.

\section{考 察}

呼吸器科領域では細胞診は大きな役割を果たしてお り, 喀痰細胞診, 気管支鏡での擦過 - 洗浄細胞診 ${ }^{3)}$, 胸水 細胞診や胸水洗浄細胞診 ${ }^{4}$, 経皮肺穿刺 ${ }^{5}$ あるいは腫瘍直 
Fig. 1. A) Imprint cytology of LN\#3. A cell cluster showing cohesiveness and glandular formation. A high nucleus/cytoplasm ratio and coarse granular chromatin with large nucleolei corresponded to papillary adenocarcinoma. (Papanicolaou stain $\times 400$ ) B) Histological specimen of the same node showing adenocarcinoma in the sinus area of the node. (H\&E stain $\times 100$ )

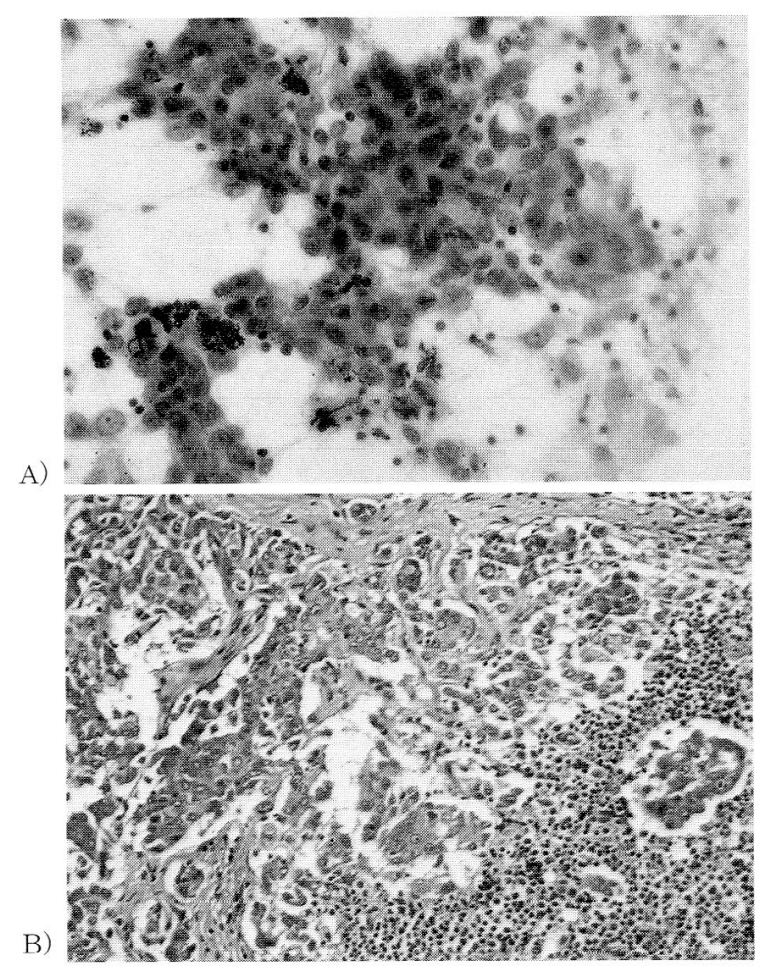

視下の穿刺細胞診, 経気管支穿刺細胞診 や捺印細胞診が 行われている。細胞診は組織から剴離した紲胞を判定す る剝離 (擦過) 細胞診と, 組織に針等を刺入して採取す る穿刺・吸引細胞診がある。一般に, 検診などのスクリー ニングとして行われるのは, 喀痰や腔などのスメアによ る剝離細胞診で, 異常が検出されたときに引き続き精查 される。これに刘し，穿刺・吸引細胞診や捺印細胞診，

気管支鏡下擦過細胞診などは疾患の病名推定・確定診断 目的として行われている7 .

細胞診は大小の検体から得られた細胞の大小不同，細 胞質の性状, 核の形・不整やクロマチン, 核小体, N/C 比等の細胞個々の外観で悪性度を判定する して, 組織診は一定以上の大きさの検体を必要とし, 検 鏡までの工程がやや複䧱であるが, 組織構造や周囲への 浸潤性の判定が可能である ${ }^{9}$. 組織診で判定するのは, 連 続する細胞集団の一スライス面である。細胞診と組織訬 には一長一短があり，実際の臨床では両方が有効に用い られている。腫瘍組織のような均一な検体の診断には連 続した細胞が構成する組織診の方が有効であろうが，リ ンパ節内への転移の有無といった不均一に広がる悪性細
Fig. 2. Imprint cytology of LN\#7. A cluster of giant cells with round to oval, hyper chromatic nuclei and orange stained cytoplasm shows a sheet-like appearance of squamous cell carcinoma. (Papanicolaou stain $x$ 400) The histological spccimen failed to show malignant cells.

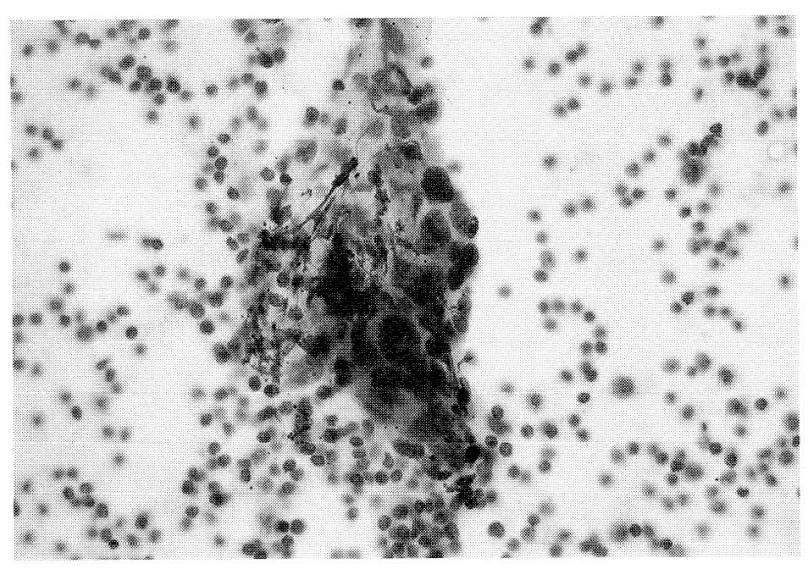

Fig. 3. Imprint cytology of LN\#7. A cluster of round cells with large nuclei and irregular nuclear margin with coarse chromatin corresponds to adenocarcinoma. (Papanicolaou stain $\times 400$ ) The histological specimen failed to show malignant cells.

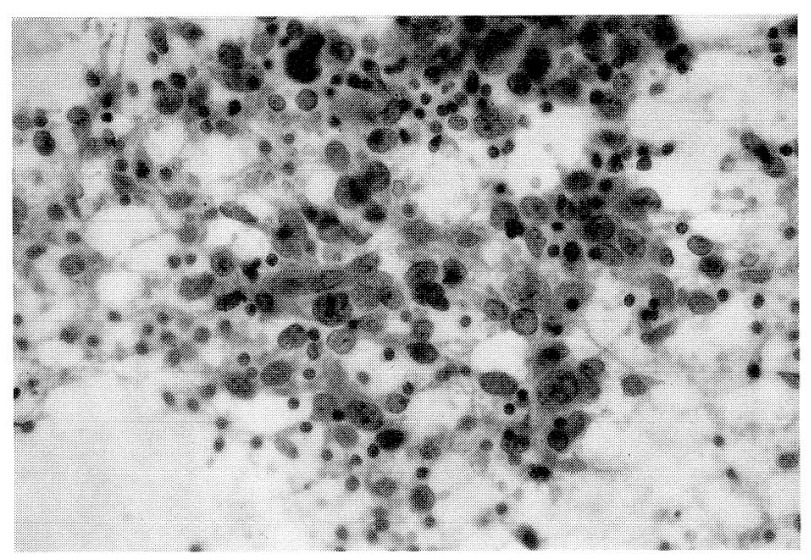

胞の有無の判定には細胞診も有用であろう.本報先では, 細胞診陽性例がすべて最終的に転移陽性と判断され, 細 胞診の有用性が示された，細胞診陽性・組織診陰性と なった理由として，採取した検休を最初に捺印して細胞 診に提供しているので，择印がなければ組織診で検出し えた可能性は否定できないが, micrometastasis は顕微鏡 標本中の一視野にしかみられないことは常に想定され， 練胞診によりこれを有效に検出したと考えられる.

Table1 に示した細胞診と組織診で我離のみられた症 例をみると, 症例 1,2 では組織診では縦隔リンパ節に転 移はみられなかったが，細胞診で\#7リンパ節に転移が 検出され，肺癌病期はN2で stage IIIAと診断された。症 
Table 1. Patients who showed discrepancy in cytological and histological examinations

\begin{tabular}{ccccccc}
\hline Patient & Age/Sex & Histology & \multicolumn{1}{c}{ Biopsy } & $\begin{array}{c}\text { Positive nodes - } \\
\text { Cytology }\end{array}$ & $\begin{array}{c}\text { Positive nodes - } \\
\text { Histology }\end{array}$ & TNM-Stage \\
\hline 1 & $70 \mathrm{M}$ & Sq & $\# 3,4,7$ & $\# 7$ & - & T2N2M0 (II A) \\
2 & $73 \mathrm{M}$ & Ad & $\# 3,4,7$ & $\# 7$ & - & T2N2M0 (III A) \\
3 & $45 \mathrm{M}$ & Ad & $\# 3,7$ & $\# 3,7$ & $\# 3$ & T1N2M0 (II A) \\
4 & $78 \mathrm{M}$ & Ad & $\# 2,3,4,7$, contra 4 & $\# 3,4$, contra 4 & $\# 3,4$ & T2N3M0 (IIIB) \\
\hline
\end{tabular}

例 3 は組織診で\#3リンパ節が陽性であり, 細胞診でこ れに加えて \#7 も陽性とされた. 症例 4 は組織診で\#3, 4 リンパ節に転移がみられ, 細胞診で対側＃4リンパ節も 転移陽性となり，病期は組織診のみによる N2, stage IIIA から細胞診も加えた N3, stage IIIB と診断された。N2 肺 癌の治療方針として induction therapy が採用されつつ ある今日 ${ }^{10111)}$, 縦隔鏡生検の精度は重要である. 症例 1.2 では細胞診の結果により治療方針が大きく変更された. 症例 4 は高齢であり, N2 病変ならば外科切除を行わない 方針であったので, 症例 3.4 では細胞診結果による治療 方針の変更はなかった.

我々の施設では frozen section が利用できないところ から本研究を始めたが，これまでにリンパ節転移に対す る細胞診の有用性を検討した報告は少なく ${ }^{12)}$, 縦隔鏡生
検標本に対する検討はみられない。細胞診は簡便で短時 間で診断がえられ，その精度は組織診に劣るものでない ことが示された. 特にリンパ節への転移の有無といった 不均一組織内での悪性細胞診断において有用であると考 えられ，このことはさらなる症例の積み重ねによって検 証されるだろう。

\section{結 語}

肺癌患者の縦隔リンパ節の転移診断に細胞診・組織診 を行い, 細胞診の有効性を検討した，組織診陽性例では すべて細胞診陽性であり, 細胞診のみ陽性が 4 例 4 stationsにみられ, 最終的に細胞診陽性例が転移陽性と判断 された.リンパ節生検の細胞診の感受性・精度は高く, その診断能力は組織診と同等かそれ以上と考えられた。

\section{文}

1) Patterson GA, Ginsberg RJ, Poon PY, et al : A prospective evaluation of magnet resonance imaging, computed tomography, and mediastinoscopy in the preoperative assessment of mediastinal node status in bronchogenic carcinoma. J Thorac Cardiovasc Surg 94 : 679-684, 1987

2) 後藤一博：術中迅速細胞診. 日外会誌 $73: 424-439$, 1972

3) Arroliga AC, Matthay R : The role of bronchoscopy in lung cancer. Clin Chest Med $14:$ 87-99, 1993

4) Buhr J, Berghauser KH, Morr H, et al : Tumor cells in intraoperative pleural lavage - an indicator for the poor prognosis of bronchogenic carcinoma. Cancer 65 : 18011804, 1991

5) Khouri NF, Stitik FP, Erozan YS, et al : Transthoracic needle aspiration biopsy of benign and malignant lung lesions. AJR Am J Roentegnol 144 : 281-288, 1985

6) Harrow EM, Oldenburg FA, Lingenfelter MS, et al : Tranbronchial needle aspiration in clinical practice. Chest 96 :

1268-1272, 1989

7）坂本穆彦：細胞診断学の基礎. 臨床細胞診断学アトラス, 文光堂, 東京, 1-13 頁, 1993

8）日本肺癌学会編：臨床・病理 肺癌取り扱い規約. 金原 出版, 東京, 1999

9）沢田勤也：術中細胞診. 肺癌の細胞診, 医学書院, 東京, 19-20 頁, 1985

10) Kirn DH, Lynch TJ, Mentzer SJ, et al : Multimodality therapy of patients with stage IIIA, N2 non-small cell lung carcinoma with mediastinal lymph node metastases (N2M0). J Thorac Cardiovasc Surg 106 : 696-702, 1993

11) Mathisen DJ, Wain JC, Wright CD, et al : Assessment of preoperative accelerated radiotherapy and chemotherapy in stage IIIa (N2) non-small cell lung cancer. J Thorac Cardiovasc Surg $111: 123-133,1996$

12）塚田博, 赤荻栄一, 小川功, 他：摘出リンパ節割面からの 塗抹細胞診による肺癌リンパ節転移の診断. 日胸疾会誌 $30: 91-94: 1992$ 


\title{
Imprint cytology for detecting metastasis of lung cancer in mediastinal lymph nodes
}

\author{
Kenichi Okubo', Tatsuo Kato², Isao Okazaki ${ }^{3}$, Yasumasa Kani ${ }^{3}$, Nobuhiro Miyamoto', \\ Toshihiro Okamoto ${ }^{1}$, Yasunori Kurahashi ${ }^{1}$, Naoki Yoshimi ${ }^{4}$
}

1. General Thoracic Surgery, Gifu National Hospital

2. Pulmonary Medicine, Gifu National Hospital

3. Department of Laboratory Medicine, Gifu National Hospital

4. First Department of Pathology, School of Medicine, Gifu University

Objective : We studied the effectiveness of cytological diagnosis for detecting metastasis of lung cancer in mediastinal lymph nodes.

Methods : One hundred forty stations of mediastinal nodes in 50 patients with lung cancer were excised through mediastinoscopy. Each specimen was examined for metastasis with imprint cytology and hematoxylin-eosin stained histology. Sensitivity and accuracy were compared between cytological and histological examinations.

Results : Cytological examination showed 22 positive stations in 14 patients, while histological examination showed 18 positive stations in 12 patients. All histological positive stations were positive cytologically and the final diagnosis was identical with cytological examination. The sensitivity and accuracy of cytological examination were 100\% and 100\%, while those of histological examination were $81.8 \%$ and $97.1 \%$.

Conclusion : Imprint cytology for detecting metastasis in mediastinal lymph nodes showed high sensitivity and accuracy, and was no less effective than histological examination.

[JJLC $40: 107 \sim 110,2000]$ 